\title{
How to measure intangible cultural heritage value? The case of flamenco in Spain
}

\begin{abstract}
This paper designs an empirical methodology to measure the perceived value of intangible cultural heritage, specifically using the significant example of flamenco. Such methodology is divided into three stages: interviews with experts, to lay out the flamenco creation process and to identify the aspects, which influenced its value; a double system survey for spectators and experts, which determines the perceived valuation of stated aspects, and finally, a correlation and exploratory factor analysis whose results identified three influencing factors on the valuation of flamenco: feelings, virtuosity and composition elements. The conclusions show how feelings are the key element in its valuation, representing the highest proportion of the accumulated total variance. Due to its findings, this methodology creates a precedent for intangible cultural heritage valuation, which applies to those music genres characterized by local idiosyncratic elements in their creation, such as vallenato (Colombia), and doina (Romania), among others.
\end{abstract}

Keywords: perceived value, intangible cultural heritage, flamenco, exploratory factor analysis, feelings.

JEL Code: Z11

\section{Introduction}

There is a growing need to raise empirical issues related to intangible cultural heritage ${ }^{1}$ for its reappraisal (Anderson, 1993; Klamer, 2003; Thomas, 2007; Hernando \& Campo, 2017a). Valuation is related to the aesthetic experience, which stimulates the recognition of different dimensions of the perceived value, such as aesthetic, symbolic, cognitive or social, among others (Vecco, 2010; Christensen \& Calvo-Merino, 2013; Vicary et al., 2017). Moreover, it must be founded on the community's ability to recognize these dimensions, upon which its own cultural identity is built.

This article adopts an empirical approach for the perceived value of intangible cultural heritage, specifically flamenco. Flamenco is a music genre included in the UNESCO Representative List of the Intangible Cultural Heritage of Humanity since 2010. Likewise, it is a shared practice to which artists contribute, but which also needs active listening, a strong sense of community, a history and local idiosyncratic elements (Romero, 1996; Aoyama, 2009; Heredia-Carroza et al., 2019a). These shared features alongside other cultural heritage manifestations make the case of flamenco ideally suited for this research.

For that purpose, it develops a methodology based on three approaches: firstly, by means of interviews with experts, it lays out the creation process of flamenco, determining its agents and their contributions; secondly, through a double system survey applied to spectators ${ }^{2}$ and experts ${ }^{3}$, it creates an ad hoc data base to quantify the 
perceived value of these creative contributions (Noonan, 2003; Lundy \& Smith, 2016); and, finally, it carries out an analysis of correlations and exploratory factor analysis by principal components to identify three factors that influence the perceived value of flamenco (Tschacher et al., 2015).

These factors (feelings, virtuosity, and composition) represent flamenco's distinguishable elements (Choi et al. 2007; Lee \& Min, 2012; Heredia-Carroza, 2019). The main results show how feelings are the key element in its valuation, which represents more than $52 \%$ of the accumulated total variance from spectators and more than $40 \%$ from the experts (Pantti, 2010).

The article contributes to empirical literature on experimental aesthetics in three aspects: i. Its methodology creates a precedent for intangible cultural heritage valuation, which can be used as an instrument to measure value. ii. It identifies the stages and elements of flamenco creation, which also applies to other traditional popular music genres characterized by their local idiosyncratic elements. iii. It measures the perceived value of flamenco through synthetic indexes based on feelings as the most influencing factor for spectators and experts.

\section{Flamenco as intangible cultural heritage of humanity}

Flamenco, from cultural economics perspective, is defined as a complex cultural good (Throsby, 2010). Firstly, it is a traditional popular music genre (Von Tongeren, 2017) whose territorial roots are bind to customs and traditions reflected in the cultural heritage of Andalusia in Spain (Cruces 2001; Aoyama, 2009; Manuel, 2010). Secondly, it covers different creative disciplines -it emerges from the vocal music, which is cante,- but it integrates most commonly together with instrumental music, corresponding to toque, and dance or baile (Infante, 1980; Palma et al., 2017). Thirdly, it contains a clear symbolic message perceived by the audience (Vecco, 2010).

Flamenco is characterized by special aesthetics, performative and socio-cultural features, such as opposed trends (pure flamenco versus flamenco fusion) (Aix Gracia, 2002) and the importance of the local environment or the blend of cultures (Romero, 1996; Cruces, 2001; Manuel, 2010). Its repertoire is also influenced by a strong oral tradition (Prouty, 2006) and its constant evolution. All of these features allow its consideration as an arte vivo (Bermúdez \& Pérez, 2009).

Its musicians have traditionally learned from empirical and natural form (Blacking, 1981; Donnier, 2011). The transmission of flamenco is learned from one generation to another directly. The use of musical scores is not customary. Thus, the externalization ${ }^{4}$ is a key stage of flamenco (Edinborough, 2012; Heredia-Carroza et al., 2019a), see Figure 1.

Figure 1: Framework of flamenco

Own elaboration

This article designs a new methodology to measure the cultural value of intangible cultural heritage, focused on flamenco due its recognition by UNESCO. To this end, it uses the concept of perceived value as an approximation of the cultural 
value. It has followed Anderson (1993: 2) who defends: 'to value something is to have a complex of positive attitudes toward it, governed by distinct standards for perception, emotion, deliberation, desire, and conduct'. Upon evaluating perceptions, it creates a sense of a valuation. As mentioned by Klamer (2003:10) 'while valuing something can be a spontaneous process, evaluation involves the conscious reflection on the reasons for a valuation'.

This idea focuses on the perception and recognition of intangible cultural heritage, concretely flamenco. A small number of researches have taken this approach on the perceptual, emotional, and cognitive processes engaged during aesthetic experience (Christensen \& Calvo-Merino, 2013). One of the main contributions of this paper is that it will provide a methodology that can be replicated with intangible cultural heritage disciplines, such as traditional popular music genres with performative features similar to those of flamenco (vallenato, salsa in Colombia, doina in Romania, among others).

\section{Method}

\section{Participants}

In the light of the lack of literature, this research had to rely on qualitative information. Thus, 15 of the most outstanding flamenco and Spanish music industry experts ${ }^{5}$ were interviewed (Arboleda \& Gonzalez, 2016; Heredia-Carroza et al., 2019b). These experts are authors who also perform; politicians responsible for cultural affairs, representatives of the two most important Spanish copyright management entities: Sociedad General de Autores y Editores (SGAE) and Asociación de Artistas, Intérpretes y Ejecutantes (AIE); cultural managers of important flamenco festivals such as Bienal de flamenco de Sevilla and the Festival de Jerez de la Frontera, among others. The selection criteria of the interviewed experts were their relevance, considering specifically awards obtained in the case of artists (Latin Grammy, Masters of Mediterranean Music of Berklee College of Music, Medalla de Oro al Mérito en las Bellas Artes, among others), festivals managed in the case of cultural managers and the level of responsibility with regard to cultural-related themes.

Afterwards, 696 surveys were conducted for two audience agents of flamenco (Hekkert \& Van Wieringen, 1996; Lundy \& Smith, 2016). The first agent, spectators, makes up for 586 of those surveys. The second one, experts, group data from qualified cultural managers with 59 surveys and critics with 51 (Holbrook, 1999). Spectators represent the demand considering their participation and monetary votes. Cultural managers design artistic programs, acting as intermediaries between flamenco and spectators. Finally, critics give recognition to flamenco shows with their publications and opinions in the media (TV, radio and press), or contests (Hutter \& Frey, 2010; Dekker, 2015).

Descriptive statistics reported in Table 1 show the features of the participants. On the one hand, spectators were balanced for sex and all the age ranges with a high educational level. They were also familiar with flamenco, as their knowledge and time- 
consuming flamenco music prove. On the other hand, experts preponderantly are men with a high educational level and higher age than spectators are.

Table 1: Descriptive Statistics

Data collected from the surveys

\section{Materials and Procedure}

\section{Interviews}

The information collected from the interviews, enabled a better understanding and knowledge about flamenco. These interviews were structured in three parts: first, they inquired about its creation process and the elements that influence the perceived value of flamenco, and which also affect its success (Hadida, 2010); the second part expands on copyright issues and, finally, a general section dedicated to future studies. Each interview lasted from 60 to 90 minutes, and they were carried out between January and May 2017. This paper uses the information obtained in the first part.

At this stage, the elements identified serve as the basis for the design of flamenco's creation process (Heredia-Carroza et al., 2019a). Experts concur that flamenco starts when the author resorts to a pre-existing creative source known as cultural heritage. That creative source derives in a musical form known as palo ${ }^{6}$. The author selects the palo, with its own rhythmic and harmonic features, which scope the flamenco expression (Rosón, 2010; Heredia-Carroza et al., 2017).

Subsequently, the author adds its personal elements such as melodies and lyrics, producing a musical composition. Finally, through the externalization of flamenco, the performer combines composition elements with its own elements, such as the concept of cultural heritage and its differentiating talent, enabling the recreation of what the author sets (Heredia-Carroza et al., 2019b).

According to the experts and specific bibliography (Romero, 1996; Manuel, 2010; Márquez Limón, 2017), performer's differentiating talent, which makes the flamenco experience unique and irreplaceable for the audience, materializes through virtuosity and feeling components (Cotter et al., 2019). The first consists of elements such as: ability to improvise, technique features, distinctive elements, consistency and innovation of its performance. The second covers subjective elements, such as the ability to produce emotion, to generate reflection in spectators, and to feel and make others feel flamenco (Heredia-Carroza, 2019).

\section{Surveys}

Once, the main aspects of flamenco were identified, the double system survey for spectators and experts came into play (Hutter \& Frey, 2010; Radbourne et al., 2009; Radbourne et al., 2010). It allowed building an ad hoc database with the observations, as well as measuring the perceptions of creative agents and their contributions to flamenco. Online surveys were carried out between May and September 2017 the instruments were disseminated by Flama. La Guía del flamenco, Centro Andaluz de 
Documentación del Flamenco and promocionmusical.es ${ }^{7}$ website (Palma et al., 2017; Heredia-Carroza et al., 2019a; Heredia-Carroza et al., 2019b).

The survey instruments were divided into five sections. In the first section, flamenco consumption habits and professional profiles, and the knowledge of flamenco were requested; the second section carried out questions related to flamenco aspects and its creative agents' valuation; the third section focused on the level of agreement/disagreement with some statements about flamenco artists (authors and performers). Then, the fourth section asked questions about cultural policy; and finally, it inquired about socio-economic aspects ${ }^{8}$.

This article focuses on aspects from the second section. The questions followed on a Likert scale from one to seven points, with an eighth 'do not know, non-response' option (Hernando \& Campo, 2017b). Table 2 shows the descriptive statistics of section two. The data demonstrate how spectators and experts, through their high valuation of stated aspects, verified the creation process of flamenco and gave importance to its externalization like the last stage of its creation (Heredia-Carroza et al., 2019a).

Due to the 'do not know, non-response' option, data sets are not complete. According to Schuschny \& Soto (2009), it is possible to make artificial imputations when the missing data accounts for less than $15 \%$ of the available information (GarcíaSánchez et al, 2015). In this research, the level of missing values for spectators is of 3 , $64 \%$ and $2.79 \%$ for experts. In addition to the above-mentioned criteria, to select the best technique for missing data imputation, it was also important to check the pattern of the missing information. Finally, before starting the empirical analysis, the multiple imputation method was used for these missing values (García-Sánchez et al., 2015). According to Horton \& Lipsitz (2001), this method remains ideally suited to this kind of data set, this comprehensive information about the analysis can be used to 'fill-in' or impute sets of values for incomplete observations.

Table 2: Descriptive Statistics

Data collected from the surveys

This useful information reduces uncertainty about the characteristics of flamenco. The article identifies which variables influence its perceived value (Hernando \& Campo, 2017b), and to test this, it used a two exploratory factor analysis by principal components (Malthouse \& Calder, 2002; Srakar et al., 2017; Gómez-Vega \& HerreroPrieto, 2019) one aimed at spectators, and other focused on experts. An exploratory factor analysis makes sense if there are high correlations between the variables, since this is indicative of redundant information and, therefore, few factors will explain much of the total variability. Next section begins with the results from the correlation analysis.

\section{Results}

\section{Analysis of correlations}

Analyses of the correlations show the relations between the explained variables, see Tables 3 and 4. These correlations are statistically significant at 99\%. In the case of the 
spectators and experts, the highest correlations reveal significant results, mainly between 'make others feel the flamenco' and 'ability to feel flamenco'; 'make others feel flamenco' with 'ability to produce emotions' and 'make others feel flamenco' with 'ability to produce emotions'. In addition, it is important to underline the correlation between 'melody' and 'rhythm', which identifies as the author contributions to the composition.

Following, for spectators, from the correlations between 'distinctive element', 'technique' and 'improvisation', which is higher than 0.6 , one of the most important features of flamenco was confirmed: its consideration as an arte vivo. It depends directly on its externalization in front of the audience (Bermúdez \& Pérez, 2009; Heredia-Carroza et al., 2019b). Specifically, the research finds the correlations between 'distinctive element' and emotional aspects, interesting. It demonstrates how the experiences of flamenco audience underline the performer's role, who ultimately relates audiences' perceptions with the moment of externalization (Beauvois, 2007; Jola et al., 2012).

For experts, the highest correlations are the same as spectators. However, in some interesting cases, with a correlation higher or close to 0.6: 'melody' and 'rhythm', 'rhythm' and 'harmony', and 'melody' and 'harmony, an explanation is needed. Theses correlations show how experts visualize the role of the composition, because their specialized training and accumulated experience allows them to have a deeper knowledge about it (Holbrook, 1999). Finally, correlations above 0.5: 'improvisation' and 'technique'; 'innovation of the performance' and 'improvisation'; and 'innovation of the performance' and 'distinctive element', demonstrate the need to have a seasoned technique to improvise, and the importance of the improvisation in an innovative performance (Blacking, 1981; Donnier, 2011; Edinborough, 2012).

A first approach can reflect an order of distinguishable elements that seem to influence the value of the flamenco: emotional aspects, composition ones, and the virtuosity of the performance. In order to offer empiric evidence, an exploratory factor analysis is done by principal components to know the subjacent structure of the data (Malthouse \& Calder, 2002; Hernando \& Campo, 2017a; Au et al., 2016; Lundy \& Smith, 2016).

Table 3: Correlations among variables valued by the spectators

Own sources

Table 4: Correlations among variables valuated by experts

Own sources

\section{Exploratory Factor Analysis}

Two exploratory factor analyses were performed on the whole sample (586 spectators and 110 experts). The 13 variables specified earlier underwent a factor analysis using maximum likelihood estimation with varimax rotation. Accuracy of the model fit was tested through Bartlett's Test of Sphericity and Kaiser-Meyer-Olkin. Table 5 shows the results of the exploratory factor analysis for spectators and experts, respectively. Both 
identify three factors that summarize the distinguishable elements that influence the valuation of the flamenco explaining more than $70 \%$ of the total accumulated variance for spectators and more than $64 \%$ for experts.

Table 5: Results of the Exploratory Factor Analysis for spectators and experts

\section{Own sources}

As it can be seen in Table 5, the first factor called 'feelings' brings together the following variables: 'ability to produce emotions', 'generate reflection in spectator', 'ability to feel flamenco' and 'make others feel flamenco'. The second one, 'virtuosity', includes the 'distinctive element', 'technique', 'improvisation', 'consistency of the performance', and 'innovation of the performance'. Finally, the factor named 'composition elements' grouped: 'harmony', 'rhythm', 'melody' and 'lyrics' (Radbourne et al., 2009; Chan et al., 2016).

\section{Discussion}

Aspects that emanate from the subjective element of the flamenco (Bermúdez \& Pérez, 2009) integrate feelings. Taking up the multi-dimensionality of the cultural value, they have the relation with its emotional dimension (Au et al., 2016; Hernando \& Campo, 2017b).

According to Cotter et al. (2019), when the music is viewed in terms of subjective qualities, it is rated as more complex and beautiful, even familiar, personally meaningful and lyrical. In this sense, the social and environmental aspects are very important for the kind of feelings originated, for example, when the music reminds the spectators of someone they knew (Launay et al., 2016; Heredia-Carroza et al., 2017). It seems common that feelings are a response to musical features of flamenco, such as its beauty and vastness (Romero, 1996; Manuel, 2010). Indeed, flamenco shows an enormous range of feelings, so this abstraction should not obscure the heterogeneity in people's aesthetic experiences (Cotter et al., 2019).

The virtuosity factor integrates the elements linked to the aesthetic dimension of the cultural value (Shanahan, 1978; Lazzaro, 2006; Vartanian et al., 2015) that derived from aspects such as innovation, improvisation, or artist's technique, among others. So far, the aesthetic dimension is related to specific time-sensitive relationships between the externalization and the spectator's response (Felton, 1978; Au et al., 2016; Edinborough, 2012; Heredia-Carroza et al., 2019b).

Vicary et al. (2017) demonstrate that some of the aesthetic appeal of the performing arts lies in communicating between a group of performers to a group of spectators and this is only possible through the performance elements that induce visual and hearing stimuli (Schroeder, 1191; Beauvois, 2007).

The composition elements factor is composed of the variables linked to composition (harmony, rhythm, melody, and lyrics) that may be associated with the cognitive dimension of the cultural value (Holbrook and Hirchman, 1982; Au et al. 2016). In this factor, study and comprehension of musical forms and the message of the music are key (Tschacher et al., 2015; Hernando \& Campo, 2017a). 
This cognitive demand may be a tall order for most flamenco listeners, even those familiar with the relevant musical grammar. Despite the fact that some listeners may fail to distinguish between palos, they still acknowledge the difference they make for composition (Eitan \& Granot, 2008). See Figure 2.

Figure 2: Distinguishable elements in the valuation of flamenco Own elaboration

This research emphasized describing flamenco as an interactive process, which takes place before, during and after the externalization. Spectators and experts perceive these moments: ex ante aspects (the joining of flamenco's cultural heritage and flamenco's author creation); the moment of the externalization (virtuosity of the performer); and, ex post aspects (feelings) (Jola et al., 2012). This relates to the Leder et al.'s (2004) thesis, which considers that aesthetic experience begins with the expectations, anticipations and an aesthetic orientation (Leder \& Nadal, 2014). Therefore, flamenco's experience would begin with these expectations related to composition aspects, but the audience can only perceive and evaluate flamenco value when it is externalized (Bergeron \& Lopes, 2012). This is because the use of scores is not very common in flamenco, and the perceptions of the audience almost depend entirely on live or recorded music.

Going back to the analysis by spectators and experts, there are similarities in the valuation of factors and elements that compose them. The factors' order and composition are the same for both: feelings, virtuosity and composition elements. This may be understood as the expert eye vs. the non-expert eye valuating in the same way when they watch flamenco (Hekkert \& Van Wieringen, 1996). This reinforces and gives reliability to the measurement scale that this paper develops. Considering that 'feelings' accounts for more than $52 \%$ of the total accumulated variance for spectators and more than $40 \%$ for experts, it may be used as a synthetic index reflecting key common elements that influence the valuation of flamenco (Srakar et al., 2017; Gómez-Vega \& Herrero-Prieto, 2019), see Table 6.

Table 6: Indexes for the valuation of flamenco

\section{Own sources}

These indexes are generally applicable and reasonably organized to measure perceived value of the flamenco. Not only do they provide a rather comprehensive conceptualization of the audience agents' perceptions, but also their categories are consistent with respect to the requirements of experts who were interviewed (Au et al., 2016). Without a shadow of a doubt, the two elements are: 'ability to produce emotions' and 'make others feel the flamenco', which are both clearly related to the subjective element of flamenco associated with the emotional dimension of the cultural value (Lee et al., 2012; Leder \& Nadal, 2014; Perez-Alvaro \& Manders, 2016).

\section{Conclusions}

The paper develops a useful methodology for intangible cultural heritage valuation, specifically for flamenco. The methodology combined qualitative and quantitative 
instruments: interviews with experts and a double system survey to spectators and experts, respectively. The first one helped to design the creation process of flamenco and to identify the aspects that make up its perceived value. The second one allowed the valuation of given aspects. That valuation later enabled a correlation analysis that lead to an exploratory factor analysis by principal components to learn the subjacent structure of the data.

Besides, the results help to understand audience perceptions from two perspectives: spectators and experts. They differentiate three distinguishable elements: composition elements (author's composition), virtuosity (performer differentiating talent) and, as a result of the combination of these two, feelings (audience perceptions). This is consistent with the creation process of flamenco explained before and, from the scope of cultural economics, with the multi-dimensionality of the cultural value.

Feelings' factors provide a high explanation of the accumulated variance, so they can be used as a synthetic index for the valuation of the flamenco. They have a great importance as they provide recording companies, an instrument that reduces uncertainty about the characteristics of the music and that can also be used as a managerial decision instrument, based on empirical evidence about spectators and experts' perceptions.

Finally, the article uses a proper terminology for the valuation of music such as differentiating talent of the performer, distinguishable elements and externalization, or the nomenclature used for the three factors. This terminology, together with the explained methodology can be replicated with other intangible cultural heritage disciplines, concretely with traditional popular music genres with performative features similar to flamenco, such as vallenato or salsa in Colombia and doina in Romania, among others.

\section{Acknowledgments}

The authors are grateful to Francisco Heredia Carroza, MSc. MaríaJosé Mejía and MSc. Laura Díaz for many helpful discussions and comments, as well as with all the interviewed experts, the organizations, which disclosed the survey: Flama. La guía del Flamenco, Centro Andaluz de Documentación del Flamenco and the website Promocionmusical.com, and finally with the people who took the survey.

\section{Declaration of Conflicting Interests}

No potential conflict of interest was reported by the authors.

\section{Funding}

The first author disclosed receipt of financial support for the research, authorship, and/or publication of this article. The authors acknowledge financial support from Asociación Universitaria Iberoamericana de Postgrado.

\section{References}

Anderson, E. (1993). Value in Ethics and Economics, Cambridge: Harvard University Press. 
Aix Gracia, F. (2002). El arte flamenco como campo de producción cultural. Aproximación a sus aspectos sociales. Revista andaluza de Ciencias Sociales 1, 109-125.

Aoyama, Y. (2009). Artist, Tourists, and the State: Cultural Tourism and the Flamenco Industry in Andalusia, Spain. International Journal of Urban and Regional Research, 33(1), 80-104. Doi: 10.1111/j.1468-2427.2009.00846.x.

Arboleda, A. M. \& González, J. F. (2016). Creating competitive advantage: the exoticism of tango and salsa from Cali, Colombia. International Journal of Arts Management, 19(1), 42-53.

Au, W. T., Ho, G. \& Chan, K. W. C. (2016). An Empirical Investigation of the Arts Audience Experience Index. Empirical Studies of the Arts, 35(1), 27- 46. Doi: $10.1177 / 0276237415625259$.

Beauvois, M. W. (2007). Quantifying aesthetic preference and perceived complexity for fractal melodies. Music Perception: An Interdisciplinary Journal, 24(3), 247-264. Doi: 10.1525/mp.2007.24.3.247.

Bergeron, V. \& Lopes, D. M. (2012). Aesthetic theory and aesthetic science. In A. P. Shimamura \& S. E. Palmer (Eds.), Aesthetic science. Connecting minds, brains, and experience, 61-79. New York: Oxford University Press.

Bermúdez S. \& Pérez, J. (2009). Introduction: Spanish Popular Music Studies. Journal of Spanish Cultural Studies, 10(2): 127-133. Doi: 10.1080/14636200902990661.

Blacking, J. (1981). Making artistic Popular Music: the goal of true Folk. Popular Music, 1, 914.

Bourdieu, P. (1984). Distinction, Cambridge, MA: Harvard University Press.

Cameron, S. (2011). Criticism. In R. Towse, ed., A Handbook of Cultural Economics, second edition, 138-141. Cheltenham: Edward Elgar Publishing.

Colbert, F. (2011). Management of the arts. In R. Towse, ed., A Handbook of Cultural Economics, second edition, 261-265. Cheltenham: Edward Elgar Publishing.

Cotter, K. N., Prince, A. N., Christensen, A. P. \& Silvia, P. J. (2019). Feeling like crying when listening to music: exploring musical and contextual features. Empirical Studies of the Arts, 37(2): 119-137. Doi: https://doi.org/10.1177/0276237418805692.

Chan, M. K., Au, W. T., \& Ying, C. (2016). Developing Validating a Theater Experience Scale. Empirical Studies of the Arts, 35(2), 169-193. Doi: 10.1177/0276237416662737.

Choi, A. S., Papandrea, F. \& Bennett, J. (2007). Assessing cultural values: developing an attitudinal scale. Journal of Cultural Economics, 31(4), 311-335. Doi: 10.1007/s10824-007-9045-8.

Christensen, J. F. \& Calvo-Merino, B. (2013). Dance as subject for empirical aesthetics. Psychology of Aesthetics, Creativity, and the Arts. 7(1), 76-88. Doi: 10.1037/a0031827.

Cruces Roldán, C. (2001). El flamenco como Patrimonio. Anotaciones a la Declaración de la Voz de la Niña de los Peines como Bien de Interés Cultural, Sevilla: Bienal de Arte Flamenco.

Dekker, E. (2015). Two approaches to study the value of art and culture, and the emergence of a third. Journal of Cultural Economics, 39(4), 309-326. Doi: 10.1007/s10824-014-9237$\mathrm{y}$.

Donnier P. (2011). Descripción multimedia del flamenco. ¿Un nuevo medio de transmisión oral?, en José Miguel Díaz-Bañez \& Francisco Javier Escobar Borrego (Eds.): Investigación y flamenco. Sevilla: Signatura, 83-95.

Edinborough, C. (2012). Form and Spontaneity: training of improvisation in football and theatre. Theatre, Dance and Interpretation Training, 3(2), 199-207.

Eitan, Z. \& Granot, R. Y. (2008). Growing oranges on Mozart's apple tree: 'inner form' and aesthetic judgment. Music Perception: An Interdisciplinary Journal, 25(5), 397-418. Doi: $10.1525 / \mathrm{mp} .2008 .25 .5 .397$.

Felton, M. V. (1978). The Economics of the Creative Arts: the case of the composer. Journal of Cultural Economics, 2(1), 41-61. Doi: 10.1007/BF02479731. 
García-Sánchez, I., das Neves Almeida, T. A. \& Paes de Barros Camara, R. (2015). A proposal for a Composite Index of Environmental Performance (CIEP) for countries. Ecological Indicators, 48, 171-188.

Doi: https://doi.org/10.1016/j.ecolind.2014.08.004.

Gómez-Vega, M. \& Herrero-Prieto, L. C. (2019). Measuring emotion through quality: evaluating the musical repertoires of Spanish symphony orchestras. Journal of Cultural Economics, 43(2), 211-245. Doi: https://doi.org/10.1007/s10824-018-9337-1.

Hadida, A. L. (2010). Commercial Success and Artistic Recognition of Motion Picture Projects. Journal of Cultural Economics, 34(1), 45-80. Doi: 10.1007/s10824-009-9109-z.

Hekkert, P. \& Van Wieringen, P. C. W. (1996). Beauty in the Eye of Expert and Non-expert Beholders: a study in the appraisal of art. The American Journal of Psychology, 109(3), 189-407.

Heredia-Carroza, J., Palma Martos, L. \& Aguado, L. F. (2017). Originalidad Subjetiva y Copyright. El caso del flamenco en España. Anduli. Revista Andaluza de Ciencias Sociales, 16, 175-194.

Heredia-Carroza, J., Palma Martos, L. \& Aguado, L. F. (2019a). Song, performance and authorship: The case of flamenco in Spain. Trames. A Journal of the Humanities and Social Sciences, 23 (73/68), 1, 3-14. Doi: 10.3176/tr.2019.1.01.

Heredia-Carroza, J., Palma Martos, L., \& Aguado, L. F., (2019b). Flamenco y Derechos de Autor. El caso de Camarón de la Isla. Arbor, 195(791), a496. Doi: https://doi.org/10.3989/arbor.2019.791n1009.

Heredia-Carroza, J. (2019). Flamenco Performer's Perceived Value: Development of a Measurement Index. Scientific Annals of Economics and Business. Doi: http://dx.doi.org/10.2478/saeb-2019-0017.

Hernando, E. \& Campo, S. (2017a). Does the Artist's Name Influence the Perceived Value of an Art Work? International Journal of Arts Management, 19(2), 49-58.

Hernando, E. \& Campo, S. (2017b). An Artist's Perceived Value: Development of a Measurement Scale. International Journal of Arts Management, 19(3), 33-47.

Holbrook, M. B. \& Hirschman, E. (1982). The Experiential Aspects of Consumption: consumption fantasies, feelings, and fun. Journal of Consumer Research, 9(2), 132140. Doi: $10.1086 / 208906$.

Holbrook, M. B. (1999). Popular Appeal vs. Expert Judgments of Motion Pictures. Journal of Consumer Research, 26(2), 144-55. Doi: 10.1086/209556.

Horton, N., Lipsitz, S. (2001). Multiple imputation in practice: comparison of software packages for regression models with missing variables. Am. Statist, 55(3), 244-254.

Hutter, M. \& Frey, B. (2010). On the Influence of Cultural Value on Economic Value. Revue d'économie politique, 120, 35-46. Doi: 10.3917/redp.201.0035.

Infante, B. (1980). Orígenes de lo Flamenco y Secreto del Cante Jondo. Sevilla: Junta de Andalucía, Consejería de Cultura.

International Round Table: Intangible Cultural Heritage, Working Definitions. (2001). Turin, Italy. Retrieved from: https://ich.unesco.org/en/events?meeting_id=00057.

Jola, C., Ehrenberg, S. \& Reynolds, D. (2012). The experience of watching dance: phenomenological-neuroscience duets. Phenomenology and the Cognitive Sciences, 11(1), 17-37. Doi: 10.1007/s11097-010-9191-x.

Klamer, A. (2003). A Pragmatic View on Values in Economics. Journal of Economic Methodology, 10(2), 1-24. Doi: 10.1080/1350178032000071075.

Lazzaro, E. (2006). Assessing Quality in Cultural Goods: The Hedonic Value of Originality in Rembrandt's Print. Journal of Cultural Economics, 30(1), 15-40. Doi: 10.1007/s10824-005-1918-0.

Launay, J., Tarr, B. \& Dunbar, R. I. M. 2016. Synchrony as an Adaptive Mechanism for LargeScale Human Social Bonding. Ethology. 122 (10), 779-789. Doi: https://doi.org/10.1111/eth.12528.

Leder, H., Belke, B., Oeberst, A. \& Augustin, D. (2004). A model of aesthetic appreciation and aesthetic judgments. British Journal Of Psychology, 95, 489-508. 
Leder H. \& Nadal, M. (2014). Ten years of a model of aesthetic appreciation and aesthetic judgments: The aesthetic episode - Developments and challenges in empirical aesthetics, British Journal of Psychology, 105, 443-464.

Lee, J., Lee, C. \& Choi, Y. (2010). Examining the role of emotional and functional values in festival evaluation. Journal of Travel Research, 50(6), 685-696. Doi: $10.1177 / 0047287510385465$.

Lee, J. \& Min, C. (2012). Examining the role of multidimensional value in convention attendee behavior. Journal of Hospitality \& Tourism Research, 37(3), 402-425. Doi: $10.1177 / 1096348012436383$.

Lundy, D. E. \& Smith, J. L. (2016). It's tough to be a Critic: Professional vs. Non-professional Music Judgment. Empirical Studies of the Arts, 35(2), 139-168. Doi: $10.1177 / 0276237416661989$.

Malthouse, E. C., \& Calder, B. J., (2002). Measuring Newspaper Readership: a qualitative variable approach. The International Journal on Media Management, 4(4), 248-260.

Manuel, P. (2010). Composition, Authorship, and Ownership in Flamenco, Past and Present. Ethnomusicology, 54(1), 106-135.

Márquez Limón, R. (2017). La técnica vocal en el flamenco: fisionomía y tipología. (Doctoral dissertation). Universidad de Sevilla, Sevilla. Retrieved from: https://idus.us.es/xmlui/handle/11441/63972.

Noonan, D. S. (2003). Contingent valuation and cultural resources: a meta-analytic review of the literature. Journal of Cultural Economics, 27(3-4), 159-176. Doi: 10.1023/A:1026371110799.

Palma, L., Palma, M. L., Rodríguez, A., Martín, J. L., \& Cascajo, I. (2017). Live Flamenco in Spain: a dynamic analysis of supply, with managerial implications. International Journal of Arts Management, 19(3), 58-70.

Pantti, M. (2010). The value of emotion: an examination of television journalists' notions on emotionality. European Journal of Communication, 25(2), 168-181. Doi: $10.1177 / 0267323110363653$.

Perez-Alvaro, E. \& Manders, M. R. (2016). Playing the values: sound and vision of the violin of the Titanic. Journal of Cultural Heritage, 21 (September-October), 869-875. Doi: 10.1016/j.culher.2016.03.011.

Prouty, K. E. (2006). Orality, literacy, and mediating musical experience: rethinking oral tradition in the learning of jazz improvisation. Popular Music and Society, 29(3), 317334. Doi: 10.1080/03007760600670372.

Radbourne, J., Johanson, K., \& Glow, H. (2009). Empowering Audiences to Measure Quality Participations, Journal of Audience \& Reception Studies, 7(2), 360-379.

Radbourne, J., Johanson, K., Glow, H., \& White, T., (2010). The Audience Experience: measuring quality in the performing arts. International Journal of Arts Management, 11(3), 16-29.

Romero, J. (1996). La Otra Historia del Flamenco. Sevilla: Junta de Andalucía.

Rosón, T. (2010). El Flamenco como Obra Musical, Coreográfica, and Escénica. Las obras originales y derivadas: versiones, arreglos y utilización de las obras. In Castilla, M. (Ed.), El Flamenco y los Derechos de Autor, 23-38. Madrid: REUS.

Schuschny, A. and Soto, H. (2009). Guía metodológica diseño de indicadores compuestos de desarrollo sostenible. In: Comisión Económica para América Latina y el Caribe (CEAPI). Naciones Unidas, Chile.

Shanahan, J. L. (1978). The consumption of music: integrating aesthetics and economics. Journal of Cultural Economics, 2(2), 13-26.

Schroeder, M.R. (1991). Fractals, chaos, power laws: Minutes from an infinite paradise. New York: W.H Freeman.

Srakar, A. Copic, V. \& Verbic, M. (2017). European cultural statistics in a comparative perspectrive: index of economic and social condition of culture for the EU countries. Journal of Cultural Economics, 1-37. Doi: 10.1007/s10824-017-9312-2. 
Thomas, P. (2007) Determining the indeterminate. Contemporary Music Review 26(2), 129-140. Doi: $10.1080 / 07494460701250866$.

Throsby, D. (1994). The Production and Consumption of the Arts: A View of Cultural Economics. Journal of Economic Literature, 32(1), 1-29.

Throsby, D. (2003). Determining the Value of Cultural Goods: How Much (or How Little) Does Contingent Valuation Tell Us? Journal of Cultural Economics, 27(3-4), 275-285.

Throsby, D. (2010) The Economics of Cultural Policy. Cambridge, New York, Melbourne, Madrid, Capetown, Singapore, Sao Paulo, Delhi, Dubai, Tokyo: Cambridge.

Tschacher, W., Bergomi, C., \& Tröndle, M. (2015). The Art Affinity Index (AAI): an instrument to assess art relation and art knowledge. Empirical Studies of the Arts, 33(2), 161-174. Doi: 10.1177/0276237415594709.

Van Tongeren, C. (2017). Distinctive culture: Framing flamenco artistry in Polígono Sur: El arte de las Tres Mil by Dominique Abel. Journal of Spanish Cultural Studies, 18(2), 169-189. Doi: 10.1080/14636204.2017.1308633.

Vartanian, O., Navarrete, G., Chatterjee, A., Brorson Fich, L., Gonzalez-Mora, J. L., Leder, H., Modroño, C., Nadal, M., Rostrup, N., \& Skove, M. (2015). Architectural Design and the Brain: effects of ceiling height and perceived enclosure on beauty judgments and approach-avoidance decisions. Journal of Environmental Psychology, 41, 10-18.

Vecco, M. (2010). A definition of cultural heritage: from the tangible to the intangible. Journal of Cultural Heritage, 11(3), 321-324.

Doi: https://doi.org/10.1016/j.culher.2010.01.006

Vicary, S., Sperling, M., Von Zimmermann, J., Richardson, D. C. \& Orgs, G. 2017. Join action aesthetics. PLoS ONE, 12(7), e0180101.

Doi: https://doi.org/10.1371/journal.pone.0180101.

Werck, K. \& Heyndels, B. (2007). Programmatic choices and the demand for theatre: the case of Flemish theatres. Journal of Cultural Economics, 31(1), 25-41. Doi: 10.1007/S10824-006-9026-3.

\section{Endnotes}

1. According to an international Round Table of experts organized at Turin (Italy, 2001) by UNESCO, intangible cultural heritage was defined as: 'Peoples' learned processes along with the knowledge, skills and creativity that inform and are developed by them, the products they create, and the resources, spaces and other aspects of social and natural context necessary to their sustainability; these processes provide living communities with a sense of continuity with previous generations and are important to cultural identity, as well as to the safeguarding of cultural diversity and creativity of humanity'.

2. Spectator is understood as the person guided by their preferences and willing to invest resources (time and money) in their participations of live-shows and/or recording. From an economic perspective, it is affirmed that a cultural experience related to art consumption emanates from the spectator (Throsby, 1994; Werck \& Heyndels, 2007).

3. Expert is understood as the person who through specialized training and accumulated experience (Holbrook, 1999) whether by study or exercise of their profession has a high degree of artistic knowledge (Bourdieu, 1984). Thus, for the purpose of this study experts are 59 cultural managers and 51 critics. Cultural managers arbitrate the options of presentations at live concerts, they are intermediaries between performers and final spectators (Colbert, 2011); critics carry out valuations of the performers with their appreciations in the press, 
festivals, and awards presentations and play a major role in the conformation of the spectators' taste. (Cameron, 2011).

4. Externalization is understood as the last stage of the creation process of flamenco production. It is the moment in which the performer adds its differentiating talent while performing and the work reaches the audience, which can also perceive its value through the aesthetic experience (Christensen and Calvo-Merino, 2013; Heredia-Carroza et al., 2019a; Heredia-Carroza, 2019).

5. Appendix I provides the list of the interviewed experts and their distinctive features.

6. The palo is each of the traditional varieties of the flamenco such as the bulerias, alegrías, fandangos or tangos, among others. These varieties are distinguished by their specific rhythmic metrics, called compás, a delimited harmony for the music accompaniment and specific themes associated with them, e.g. sadness, happiness, love, among others (Manuel, 2010).

7. Attached, as Appendix II, is the full survey instruments.

8. Flama. La Guía del flamenco is a flamenco portal for related information, ticket sale, agendas of shows and news, from Spain and France on a monthly basis since January 2006; the Centro Andaluz de Documentación del Flamenco is an institution created in 1987, part of Consejería de Cultura of the Junta de Andalucía in 1993. It dedicates to recovery, conservation, research and disclosure of flamenco; promocionmusical.es is one of the most important websites for music business in Spanish language. 
Table 1. Descriptive Statistics.

\section{Spectators}

Experts

\begin{tabular}{|c|c|c|c|c|c|c|c|c|c|c|}
\hline Obs & Mean & SD & Min. & Max. & Variables & Obs & Mean & SD & Min. & Max. \\
\hline \multicolumn{11}{|c|}{ Socio-demographic characteristics of participants } \\
\hline 586 & 0.46 & 0.50 & 0 & 1 & Female (5.1) & 110 & 0.26 & 0.50 & 0 & 1 \\
\hline 586 & 0.54 & 0.50 & 0 & 1 & Male (5.1) & 110 & 0.76 & 0.50 & 0 & 1 \\
\hline 586 & 2.65 & 1.37 & 1 & 5 & Age (5.2) & 110 & 3.75 & 0.97 & 1 & 5 \\
\hline 586 & 4.04 & 1.21 & 1 & 5 & Education level (5.3) & 110 & 4.81 & 0.52 & 1 & 5 \\
\hline 586 & 3.88 & 1.45 & 1 & 7 & 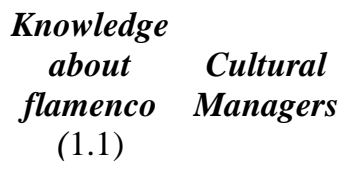 & 110 & 0.54 & 0.50 & 0 & 1 \\
\hline 586 & 3.54 & 0.87 & 1 & 4 & $\begin{array}{c}\text { Time } \\
\text { consuming } \\
\text { flamenco } \\
(1.8)\end{array}$ & 110 & 0.46 & 0.50 & 0 & 1 \\
\hline
\end{tabular}

Note. Data colleted by the surveys 
Table 2. Descriptive Statistics.

Spectators

Experts

\begin{tabular}{|c|c|c|c|c|c|c|c|c|c|c|}
\hline Obs & Mean & SD & Min. & Max. & Variables & Obs & Mean & SD & Min. & Max. \\
\hline \multicolumn{11}{|c|}{ Creative agents valued } \\
\hline 586 & 5.08 & 1.68 & 1 & 7 & $\begin{array}{c}\text { Cultural Heritage } \\
(2.1 .1)\end{array}$ & 110 & 4.55 & 1.78 & 1 & 7 \\
\hline 586 & 4.33 & 1.81 & 1 & 7 & Author (2.1.4) & 110 & 3.68 & 1.75 & 1 & 7 \\
\hline 586 & 5.62 & 1.66 & 1 & 7 & Performer (2.1.7) & 110 & 6.11 & 1.21 & 1 & 7 \\
\hline \multicolumn{11}{|c|}{ Aspects of the flamenco musical work valued } \\
\hline 586 & 5.32 & 1.50 & 1 & 7 & Harmony (2.1.2) & 110 & 5.37 & 1.40 & 1 & 7 \\
\hline 586 & 5.91 & 1.30 & 1 & 7 & Rhythm (2.1.3) & 110 & 5.65 & 1.37 & 1 & 7 \\
\hline 586 & 5.85 & 1.29 & 1 & 7 & Melody (2.1.5) & 110 & 5.57 & 1.40 & 1 & 7 \\
\hline 586 & 5.43 & 1.49 & 1 & 7 & Lyrics (2.1.6) & 110 & 4.97 & 1.53 & 1 & 7 \\
\hline 586 & 6.00 & 1.35 & 1 & 7 & $\begin{array}{c}\text { Distinctive element } \\
(2.2 .1)\end{array}$ & 110 & 5.88 & 1.19 & 1 & 7 \\
\hline 586 & 5.67 & 1.44 & 1 & 7 & Technique(2.2.2) & 110 & 5.54 & 1.30 & 1 & 7 \\
\hline 586 & 5.82 & 1.42 & 1 & 7 & Improvisation (2.2.3) & 110 & 5.43 & 1.38 & 1 & 7 \\
\hline 586 & 5.36 & 1.52 & 1 & 7 & $\begin{array}{l}\text { Consistency of the } \\
\text { performance }(2.2 .5)\end{array}$ & 110 & 5.53 & 1.39 & 1 & 7 \\
\hline 586 & 5.35 & 1.62 & 1 & 7 & $\begin{array}{l}\text { Innovation of the } \\
\text { performance }(2.2 .6)\end{array}$ & 110 & 5.24 & 1.50 & 1 & 7 \\
\hline 586 & 6.32 & 1.29 & 1 & 7 & $\begin{array}{l}\text { Ability to produce } \\
\text { emotions }(2.2 .9)\end{array}$ & 110 & 6.42 & 1.09 & 1 & 7 \\
\hline 586 & 5.66 & 1.51 & 1 & 7 & $\begin{array}{l}\text { Generate Reflection } \\
\text { in spectator }(2.2 .10)\end{array}$ & 110 & 5.46 & 1.59 & 1 & 7 \\
\hline 586 & 6.39 & 1.24 & 1 & 7 & $\begin{array}{c}\text { Ability to feel } \\
\text { flamenco }(2.2 .11)\end{array}$ & 110 & 6.11 & 1.50 & 1 & 7 \\
\hline 586 & 6.46 & 1.21 & 1 & 7 & $\begin{array}{l}\text { Make others feel } \\
\text { flamenco }(2.2 .12)\end{array}$ & 110 & 6.37 & 1.33 & 1 & 7 \\
\hline
\end{tabular}

Note. Data collected by the surveys 
Table 3. Correlations among variables valued by the spectators.

\begin{tabular}{|c|c|c|c|c|c|c|c|c|c|c|c|c|c|}
\hline & Harmony & Rhythm & Melody & Lyrics & $\begin{array}{l}\text { Distinctive } \\
\text { element }\end{array}$ & Technique & Improvisation & $\begin{array}{l}\text { Consistency } \\
\text { of the } \\
\text { performance }\end{array}$ & $\begin{array}{l}\text { Innovation of } \\
\text { the } \\
\text { performance }\end{array}$ & $\begin{array}{l}\text { Ability } \\
\text { to } \\
\text { Produce } \\
\text { emotion }\end{array}$ & $\begin{array}{l}\text { Generate } \\
\text { Reflection } \\
\text { in } \\
\text { spectator }\end{array}$ & $\begin{array}{l}\text { Ability to } \\
\text { feel } \\
\text { flamenco }\end{array}$ & $\begin{array}{c}\text { Make } \\
\text { other } \\
\text { feel } \\
\text { flamenco }\end{array}$ \\
\hline Harmony & 1 & & & & & & & & & & & & \\
\hline Rhythm & $0.5749 *$ & 1 & & & & & & & & & & & \\
\hline Melody & $0.6070 *$ & $0.7720 *$ & 1 & & & & & & & & & & \\
\hline Lyrics & $0.3985^{*}$ & $0.4279 *$ & $0.5658 *$ & 1 & & & & & & & & & \\
\hline $\begin{array}{l}\text { Distinctive } \\
\text { element }\end{array}$ & $0.4070^{*}$ & $0.4683 *$ & $0.4791 *$ & $0.3055^{*}$ & 1 & & & & & & & & \\
\hline Technique & $0.4279 *$ & $0.3640^{*}$ & $0.3998^{*}$ & $0.2889 *$ & $0.6180 *$ & 1 & & & & & & & \\
\hline Improvisation & $0.4330 *$ & $0.5295^{*}$ & $0.4926 *$ & $0.2808^{*}$ & 0.6578* & $0.6138 *$ & 1 & & & & & & \\
\hline $\begin{array}{l}\text { Consistency } \\
\text { of the } \\
\text { performance }\end{array}$ & $0.4168^{*}$ & $0.3451^{*}$ & $0.3374 *$ & $0.3220 *$ & $0.5351 *$ & $0.5285^{*}$ & $0.5438 *$ & 1 & & & & & \\
\hline $\begin{array}{l}\text { Innovation of } \\
\text { the } \\
\text { performance }\end{array}$ & $0.3165^{*}$ & $0.3534 *$ & $0.3427 *$ & $0.2507^{*}$ & $0.5749 *$ & $0.5440 *$ & $0.6106 *$ & $0.5745 *$ & 1 & & & & \\
\hline $\begin{array}{l}\text { Ability to } \\
\text { Produce } \\
\text { emotions }\end{array}$ & $0.4055^{*}$ & $0.4467 *$ & $0.4681 *$ & $0.3167^{*}$ & $0.5884 *$ & $0.4974 *$ & $0.5226^{*}$ & $0.4134 *$ & $0.4063 *$ & 1 & & & \\
\hline $\begin{array}{l}\text { Generate } \\
\text { Reflection in } \\
\text { spectator }\end{array}$ & $0.3162 *$ & $0.4008 *$ & $0.4217 *$ & $0.3352 *$ & $0.4537 *$ & $0.4185^{*}$ & $0.4639 *$ & $0.4070 *$ & $0.3880 *$ & $0.6362 *$ & 1 & & \\
\hline $\begin{array}{l}\text { Ability to feel } \\
\text { flamenco }\end{array}$ & $0.4098^{*}$ & $0.4756^{*}$ & $0.4671^{*}$ & $0.3295^{*}$ & $0.5864 *$ & $0.4924 *$ & $0.5430 *$ & $0.4259 *$ & $0.3949 *$ & $0.7102 *$ & $0.5895^{*}$ & 1 & \\
\hline $\begin{array}{l}\text { Make others } \\
\text { feel flamenco }\end{array}$ & $0.4218 *$ & $0.4893 *$ & $0.5057 *$ & $0.3454 *$ & $0.6021 *$ & $0.5097 *$ & $0.5803 *$ & $0.4299 *$ & $0.4032 *$ & $0.7718 *$ & $0.6040 *$ & $0.9201 *$ & 1 \\
\hline
\end{tabular}
* 99\% Significance level. 
Table 4. Correlations among variables valuated by experts.

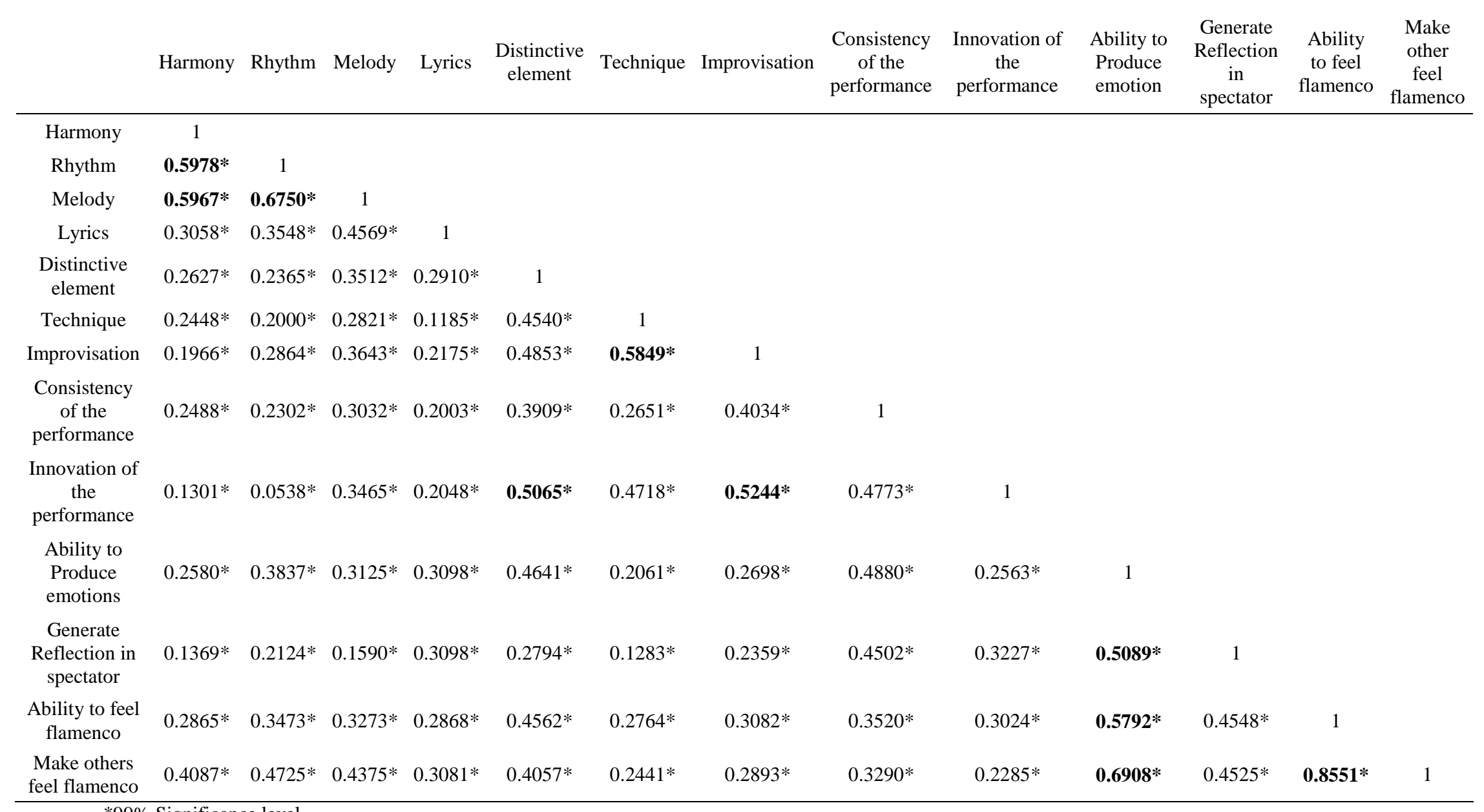


Table 5. Results of the Exploratory Factor Analysis for Spectators and Experts.

\begin{tabular}{|c|c|c|c|c|c|c|}
\hline \multicolumn{2}{|r|}{ Spectators } & \multirow[b]{2}{*}{$\begin{array}{c}\text { Percentage of } \\
\text { Variance } \\
\text { explained } \\
(\%)\end{array}$} & & \multicolumn{2}{|r|}{ Experts } & \multirow[b]{2}{*}{$\begin{array}{c}\text { Percentage of } \\
\text { Variance } \\
\text { explained } \\
(\%)\end{array}$} \\
\hline Loading & Eigenvalue & & Variables & Loading & Eigenvalue & \\
\hline & 6.76612 & 52.05 & Feelings & & 5.23831 & 40.29 \\
\hline 0.8147 & & & Ability to produce emotions & 0.8085 & & \\
\hline 0.7079 & & & $\begin{array}{c}\text { Generate Reflection in } \\
\text { spectator }\end{array}$ & 0.7413 & & \\
\hline 0.8632 & & & Ability to feel flamenco & 0.7932 & & \\
\hline \multirow[t]{2}{*}{0.8792} & & & Make others feel flamenco & 0.8023 & & \\
\hline & 1.31861 & 10.14 & Virtuosity & & 1.68661 & 12.97 \\
\hline 0.6393 & & & Distinctive element & 0.6278 & & \\
\hline 0.7018 & & & Technique & 0.7688 & & \\
\hline 0.6823 & & & Improvisation & 0.7858 & & \\
\hline 0.7416 & & & $\begin{array}{l}\text { Consistency of the } \\
\text { performance }\end{array}$ & 0.4866 & & \\
\hline \multirow[t]{2}{*}{0.8152} & & & Innovation of the performance & 0.8011 & & \\
\hline & 1.13158 & 8.7 & Composition elements & & 1.46155 & 11.24 \\
\hline 0.7053 & & & Harmony & 0.8051 & & \\
\hline 0.7748 & & & Rhythm & 0.834 & & \\
\hline 0.8419 & & & Melody & 0.8195 & & \\
\hline \multirow[t]{6}{*}{0.7041} & & & Lyrics & 0.4829 & & \\
\hline & & 70.89 & Total & & & 64.51 \\
\hline & & $\chi^{2}=5140.724$ & & & & $\chi^{2}=696.747$ \\
\hline & & df.78 & Barlett's sphericity test & & & df.78 \\
\hline & & Sig. 0.000 & & & & Sig. 0.000 \\
\hline & & 0.902 & KMO & & & 0.803 \\
\hline
\end{tabular}

Note.Own Sources.

Bold face values are most significant. 
Table 6. Indexes for the Valuation of Flamenco.

\begin{tabular}{lcc}
\hline $\begin{array}{c}\text { Flamenco } \\
\text { Musical } \\
\text { Work } \\
\text { Valuation } \\
\text { Index }\end{array}$ & $\begin{array}{c}\text { Spectators } \\
\text { Loading }\end{array}$ & $\begin{array}{c}\text { Experts } \\
\text { Loading }\end{array}$ \\
\hline $\begin{array}{l}\text { Ability to } \\
\text { Produce } \\
\text { emotions }\end{array}$ & 0.8147 & 0.8085 \\
$\begin{array}{l}\text { Generate } \\
\text { Reflection in } \\
\text { spectator } \\
\text { Ability to feel } \\
\text { flamenco }\end{array}$ & 0.7079 & 0.7413 \\
$\begin{array}{l}\text { Make others } \\
\text { feel flamenco }\end{array}$ & 0.87932 & 0.7932 \\
\hline
\end{tabular}

Note. Own Sources 
Figure I. Framework of Flamenco.

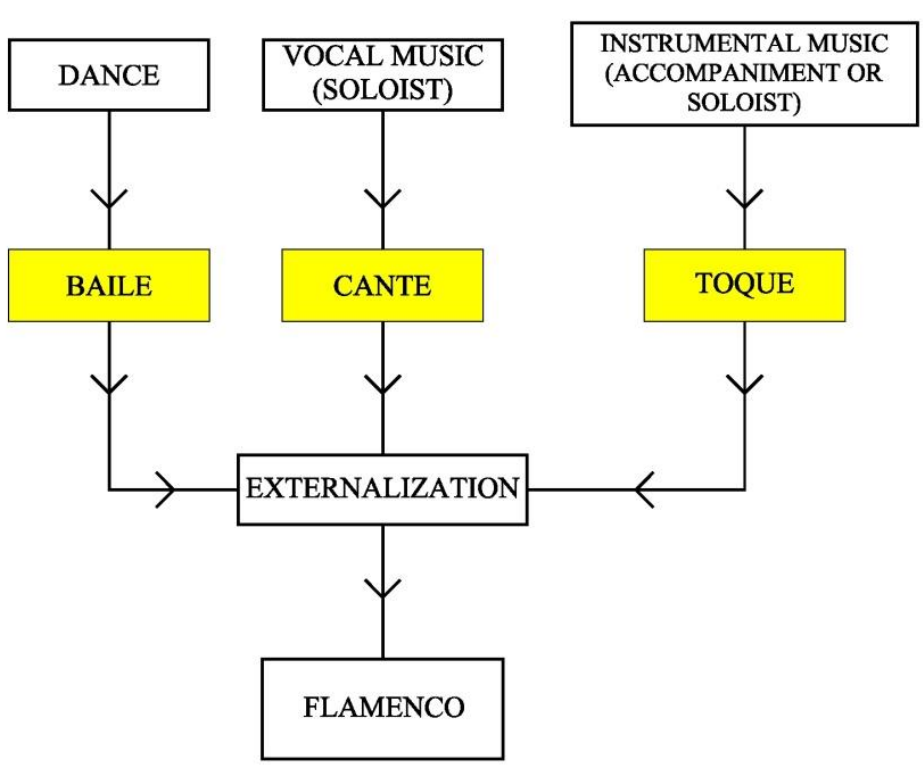

HABITS AND TRADITIONS REFLECTED IN THE

ANDALUSIAN CULTURAL HERITAGE

PERFORMER DIFFERENTTIATING TALENT

AUDIENCE PERCEPTION 
Figure 2. Distinguishable Elements in the Valuation of flamenco.

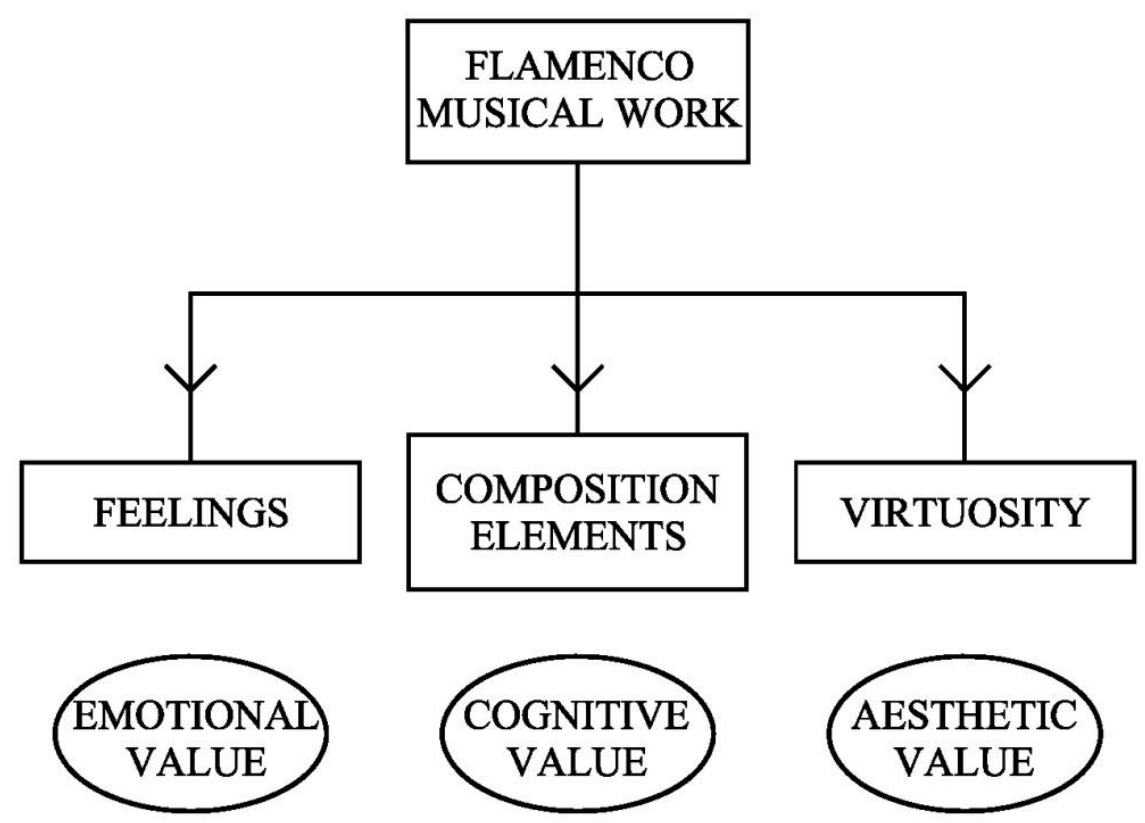

